\title{
ANALISIS PERBANDINGAN MODEL SPRINGATE, ZMIJEWSKI, DAN ALTMAN DALAM MEMPREDIKSI FINANCIAL DISTRESS PADA PERUSAHAAN MANUFAKTUR YANG TERDAFTAR DI BURSA EFEK INDONESIA
}

\author{
Diana Supriati', Icuk Rangga Bawono ${ }^{2}$, \\ Kusriyadi Choirul Anam ${ }^{3}$ \\ ${ }^{1}$ STEI Indonesia \\ Email : diana.zulham@gmail.com \\ ${ }^{2}$ Public Sector Accounting Specialist \\ Visiting Academic \\ University of Canterbury \\ Christchurch New zealand \\ Accounting Department Faculty of Economic and Business \\ Jenderal Soedirman University \\ HR Boenyamin 708nPurwokerto \\ Central Java indonesia \\ Email: cukycutes@yahoo.com \\ ${ }^{3}$ Program Studi Akuntansi, STEI Indonesia \\ Email : choirulanam.kusriyadi40@gmail.com
}

\begin{abstract}
Financial Distress can be interpreted as a phase of the decline in financial conditions experienced by a company. One of the indicators is the inability of the company to pay off its debts that are due, which is caused by losses suffered by the company in several years. This study aims to analyze and predict financial distress in companies listed on the Indonesia Stock Exchange that have suffered for several years and to find out which prediction models can indicated the best financial distress. The populations in this study are manufacturing companies listed on the Indonesia Stock Exchange in 2015-2017. The sample in this study was determined based on the purposive sampling method and obtained a sample of 16 companies, the final observation in this study were 48 observations. The data in this study were analyzed using the Springate, Zmijewski, and Altman models. This study concludes that for sample analyzed by the Springate and Altman models, the majority are classified as having indicated financial distress and for those analyzed by the Zmijewski model only a small proportion classified as having financial distress. Furthemore, for the best predictive model in indicating financial distress is the Springate model.
\end{abstract}

Keywords:Financial Distress, Springate Model, Zmijewski Model, and Altman Model 
Diana S, Icuk RB \& Kusriyadi CA, Analisis Perbandingan Model Springate...

\section{PENDAHULUAN}

Ulfa Arieza (2018), Fenomena beberapa perusahaan yang dinyatakan pailit oleh pengadilan dan beberapa perusahaan yang dikeluarkan (delisting) oleh Bursa Efek Indonesia (BEI) di tahun 2018 (www.okezone.com), ini cukup menyita perhatian para pelaku pasar. Kepailitan dan delisting mempunyai kemiripan jika dilihat dari penyebabnya, dimana kepailitan disebabkan oleh kesulitan keuangan yang dialami debitur dalam memenuhi kewajibannya baik atas permohonan para kreditur maupun atas permohonan sendiri.Adapun delisting perusahaan oleh Bursa Efek Indonesia (BEI) dapat dilakukan jika perusahaan yang tercatat mengalami sekurang-kurangnya satu dari dua kondisi yang ada.Dua kondisi tersebut adalah mengalami kondisi atau peristiwa yang secara signifikan berpengaruh negatif terhadap kelangsungan usaha perusahaan tercatat baik secara finansial atau secara hukum atau terhadap kelangsungan status perusahaan tercatat dan tidak menunjukkan indikasi pemulihan yang memadai.

Fenomena lain yang juga sedang menerpa perusahaan di Indonesia adalah kerugian usaha. Fenomena kerugian usaha ini paling dirasakan oleh perusahaan pada sektor manufaktur. Jika dirinci, perusahaan yang melaporkan kerugian di tahun 2015 sebanyak 30 perusahaan, di tahun 2016 sebanyak 28 perusahaan, dan di tahun 2017 sebanyak 34 perusahaan. Salah satu faktor utama penyebab financial distress adalah kerugian yang dialami suatu perusahaan. Kerugian tahun sebelumnya dari aktivitas operasional perusahaan akan menimbulkan arus kas yang negatif, dimana beban operasional melebihi dari pendapatan yang diperoleh (Agusti. 2013).

Financial distress merupakan kondisi kesulitan keuangan yang sedang dihadapi oleh suatu perusahaan.Financial distress juga dapat diartikan sebagai fase penurunan kondisi keuangan yang terjadi sebelum kebangkrutan ataupun likuidasi (Plat dan Plat, 2012) Financial distress dapat diawali dengan ketidakmampuan perusahaan dalam membayar hutang jangka pendek dan sekaligus jangka panjangnya. Bilamana kondisi financial distress diketahui sejak awal, tentu dapat dilaksanakan tindakan perbaikan sehingga perusahaan akan terhindar dari kondisi kesulitan keuangan yang sangat berat seperti kebangkrutan.

Salah satu metode yang dapat digunakan untuk memprediksi kondisi financial distress adalah melalui analisis keuangan. Drake (2007) analisis keuangan sebagai suatu seleksi (selection), evaluasi (evaluation), dan intepretasi (interpretation) atas data keuangan, serta menghubungkan dengan informasi lain yang dimaksudkan untuk membantu keputusan investasi dan keuangan. Salah satu informasi yang dihasilkan dari analisis keuangan adalah didapatkannya rasiorasio keuangan.Rasio keuangan menurut Aksoy dan Ugurlu (2016) dapat menggambarkan kinerja keuangan perusahaan yang sesungguhnya terjadi.

Terdapat beberapa model untuk memprediksi financial distress suatu perusahaan. Yang pertama adalah model Springate atau disebut juga S-score. Springate menggunakan metode yang sama dengan Altman 
(1968) yaitu multiple discriminant analysis (MDA). Springate hanya memilih 4 rasio dari 19 rasio yang dipergunakan dalam pengujiannya yang mampu membedakan antara perusahaan yang mengalami financial distress dan yang tidak mengalami financial distress (Wulandary dan Nur, 2014). Dari hasil pengujiannya model ini memiliki tingkat keakurasian sebesar 92\% (Ida dan Santoso.2011 dalam Kokyung dan Khairani. 2014:2).

Yang kedua adalah model Altman. Ditemukan oleh Edward L. Altman pada tahun 1968. Dalam penelitiannya Altman memilih lima rasio keuangan seperti likuiditas, profitabilitas, leverage, solvabilitas, dan aktivitas. Pada model Altman ini menemukan keakuratan pada tahun pertama dan tahun kedua sebelum kebangkrutan yaitu sebesar $95 \%$ dan $72 \%$.

Yang ketiga adalah model Zmijewski. Model ini ditemukan oleh Zmijewski pada tahun 1983 dengan melakukan riset selama 20 tahun dengan sampel 75 perusahaan bangkrut dan 73 perusahaan sehat dalam kurun waktu 1972 sampai dengan 1978. Dari penelitiannya ditemukan bahwa indicator F-test terhadap rasio rate of return, liquidity, leverage turnover, fixed payment coverage, trens, firm size, dan stock return volatility, menunjukkan bahwa adanya perbedaan signifikan antara perusahaan yang sehat dan tidak sehat (Setiawati. 2017 dalam Sari. 2014:38)

\section{KAJIAN LITERATUR \\ Landasan Teori \\ Laporan Keuangan}

Menurut PSAK No. 1 (revisi

2013) laporan keuangan merupakan suatu penyajian terstruktur dari posisi keuangan dan kinerja keuangan suatu entitas perusahaan.Laporan keuangan merupakan salah satu sumber informasi penting yang digunakan dalam pengambilan keputusan. Namun demikian, laporan keuangan (bersifat historis) menyajikan informasi apa yang telah terjadi, sehingga timbul kesejangan kebutuhan informasi. Analisis laporan keuangan digunakan untuk membantu mengatasi kesenjangan kebutuhan informasi tersebut dengan cara mengolah kembali laporan keuangan, sehingga dapat membantu para pengambil keputusan melakukan prediksi-prediksi.

\section{Rasio Keuangan}

Rasio keuangan merupakan ukuran statistik terkait dengan dua angka dari laporan labarugi, neraca atau keduanya (Halim, et al 2012 dalam Mujani. 2012:3). Salah satu tujuan dilakukannya analisis rasio keuangan adalah sebagai alat analisis untuk mengidentifikasi kekuatan dan kelemahan suatu perusahaan dimaksudkan untuk mengakses kelangsungan hidup (viability) dan menentukan return yang memuaskan akan dihasilkan dari pengambilan risiko.

\section{Financial Distress}

Financial distress merupakan kondisi kesulitan keuangan yang dialami Kesulitan keuangan ini meliputi keterbatasan kas untuk aktivitas operasi normal perusahaan hingga tertunda dan terhentinya pembayaran kewajiban-kewajiban perusahaan yang telah jatuh tempo maupun yang akan jatuh tempo. Beaver, et al (2011) dalam Dwijayanti (2010:103) mendefinisikan financial distress sebagai ketidakmampuan perusahaan untuk membayar 
Diana S, Icuk RB \& Kusriyadi CA, Analisis Perbandingan Model Springate...

kewajiban-kewajiban financial yang telah jatuh tempo. Sedangkan menurut Brigham dan Daves (2003) dalam Hidayat dan Meiranto (2014:2) kesulitan keuangan (financial distress) terjadi akibat dari serangkaian pengambilan keputusan yang kurang tepat, kurangnya pengawasan kondisi keuangan dan beberapa kelemahan yang saling terkait sehingga penggunaannya tidak sesuai dengan apa yang dibutuhkan.

\section{Faktor Penyebab Financial Distress}

Financial distress dapat disebabkan oleh faktor internal dan faktor eksternal. Agusti (2013) dalam Muflihah (2017:257) menjelaskan bahwa faktor utama penyebab financial distress dari internal perusahaan diantaranya:

1. Kerugian perusahaan

2. Besarnya jumlah hutang

3. Kesulitan arus kas

Adapun faktor utama penyebab financial distress dari eksternal perusahaan ini berupa kebijakan pemerintah yang menaikkan tarif pajak, kenaikan suku bunga pinjaman, dan fluktuasi nilai tukar mata uang terhadap mata uang negara lain. Faktor-faktoreksternal tersebut dapat menyebabkan peningkatan beban usaha yang harus ditanggung perusahaan. Model dasar kebangkrutan atau trinitas penyebab kesulitan keuangan menurut Lizal (2002) dalam Dwijayanti (2010:197) terdiri dari neoclasical model, financial model, dan corporate governance model.

\section{Tanda-Tanda Financial Distress}

Beberapa tanda-tanda kesulitan keuangan yang terlihat oleh internal perusahaan menurut Ratna dan Marwati (2018:55) diantaranya:
1. Volume penjualan yang terus menurun

2. Penurunan kemampuan perusahaan dalam menghasilkan keuntungan

3. Adanya ketergantungan perusahaan terhadap hutang dan jumlah hutang yang besar.

Adapun tanda-tanda kesulitan keuangan yang terlihat dari pihak luar perusahaan diantaranya:

1. Penurunan jumlah dividen yang dibagikan kepada pemegang saham selama beberapa periode.

2. Penurunan laba perusahaan yang terus-menerus selama beberapa periode

3. Satu atau lebh unit usaha yang ditutup atau dijual perusahaan

4. Adanya PHK terhadap karyawan secara besarbesaran

5. Penurunan harga pasar saham perusahaan yang terusmenerus

\section{Kebangkrutan}

Purnajaya dan Merkusiwati (2014:49) mendefinisikan kebangkrutan adalah suatu kondisi disaat perusahaan mengalami ketidakcukupan dana untuk menjalankan usahanya. Selain itu Widara (2010) dalam Sondakh, et al (2014:366) menjelaskan bahwa istilah bangkrut lebih mengutamakan pada usaha pencapaian tujuan dan aspek ekonomi perusahaan, yaitu berupa kegagalan perusahaan dalam menncapai tujuannya. Kegagalan tersebut menurut Gunardiansya (2009) dalam Purnajaya dan Merkusiwati (2014:49-50) dapat dirinci yaitu kegagalan ekonomi (economic failure), kegagalan keuangan (financial distressed), 
Journal of Business Administration Vol 3, No 2, September 2019, hlm, 258-270

insolvensi teknis (technical insolvency), insolvensi dalam pengertian kebangkrutan, dan legal bankruptcy. Tahapan kebangkrutan menurut Kordestani, et al (2011:278) terdiri dari:
1. Latency
2. Shortage of cash
3. Financial distress
4. Bankruptcy

\section{Model Springate}

Model

Springate

dikembangkan oleh Gorgon L.V. Springate pada tahun 1978.Model Springate merupakan model rasio yang menggunakan MDA (multiple discriminant analysis). Adapun model persamaan dari Springate sebagai berikut:

$$
S=1,03 \mathrm{~A}+3,07 \mathrm{~B}+0,66 \mathrm{C}+0,4 \mathrm{D}
$$

Keterangan:

$\mathrm{S}=$ Indeks Springate

A = Modal Kerja / Total Harta

(Working Capital to Total Assets) Modal Kerja = Aset Lancar - Kewajiban Lancar

$\mathrm{B}=$ Pendapatan Sebelum Bunga dan Pajak / Total Harta (Earning Before Interest and Taxes to Total Assets)

$\mathrm{C}=$ Pendapatan Sebelum Pajak / Kewajiban Lancar (Earning Before Taxes to Current Liabilities)

$\mathrm{D}=$ Penjualan / Total Aset (Sales to Total Assets)

Nilai cut off dari model Springate sebesar 0,862, sehingga dapat diartikan sebagai berikut:

1. Apabila nilai indeks $\mathrm{S}$ lebih dari 0,862 (>0,862), maka perusahaan diklasifikasikan tidak terindikasi mengalami financial distress.
2. Apabila nilai indeks $\mathrm{S}$ kurang dari 0,862 $(<0,862)$, maka perusahaan diklasifikasikan terindikasi mengalami financial distress.

\section{Model Zmijewski}

Model Zmijewski ditemukan oleh Zmijewski pada tahun 1983 dengan melakukan riset selama 20 tahun dalam kurun waktu 1972 sampai dengan 1978 (Sari, 2014). Dalam penelitiannya Zmijewski mengunakan sampel 75 perusahaan bangkrut dan 73 perusahaan sehat, dan diperoleh hasil yaitu ditemukan adanya perbedaan signifikan antara perusahaan yang sehat dan yang tidak sehat. Adapun model persamaan dari Zmijewski sebagai berikut:

$$
X=-4,3-4,5 X 1+5,7 \times 2-0,004
$$

Keterangan:

$\mathrm{X} 1=$ Net Income to Total Assets (ROA)

$\mathrm{X} 2=$ Debt Ratio (TLTA)

$\mathrm{X} 3=$ Current Ratio $(\mathrm{CACL})$

Nilai cut off dari model Zmijewski adalah 0 , sehingga dapat diartikan sebagai berikut:

1. Jika nilai indeks $X$ lebih besar atau sama dengan $0(>/=0)$ maka perusahaan tersebut terindikasi mengalami financial distress.

2. Jika nilai indeks $X$ kurang dari $0 \quad(<0)$ maka perusahaan tersebut tidak terindikasi mengalami Financial distress

\section{Model Altman}

Edward L. Altman melakukan penelitian pada tahun 1968 dengan mengidentifikasi perusahaan manufaktur go public yang bangkrut 
Diana S, Icuk RB \& Kusriyadi CA, Analisis Perbandingan Model Springate...

dan yang tidak bangkrut dan yang tidakdan bangkrut. Dalam penelitian itu Edward L. Altman memilih lima rasio keuangan yaitu likuiditas, profitabilitas, leverage, solvabilitas, dan aktivitas. Model Altman menemukan keakuratan pada tahun pertama dan tahun kedua sebelum kebangkrutan yaitu sebesar $95 \%$ dan $72 \%$. Adapun model persamaan dari Altmansebagai berikut:

$Z=1,2 \times 1+1,4 \times 2+3,3 \times 3+0,6 \times 4+1 \times 5$

Keterangan:

$\mathrm{X} 1=$ Working Capital $/$ Total Assets

Working Capital $=$ Current Assets Current Liabilities

$\mathrm{X} 2=$ Retained Earning / Total Assets

$\mathrm{X} 3$ = Earning Before Interest and Taxes /

Total Assets

$\mathrm{X} 4$ = Market Value of Equity / Book

Value of

Liabilities

$\mathrm{X} 5=$ Sales $/$ Total Assets

$\mathrm{Z}=$ Overall Index

Nilai cut off yang digunakan Altman adalah 1,8 dan 2,99, sehingga dapat diartikan sebagai berikut:

1. Jika nilai indeks $Z$ sebesar kurang dari 1,8 $(<1,8)$ maka perusahaan terindikasi mengalami financial distress.

2. Jika nilai indeks $\mathrm{Z}$ diantara 1,8 sampai dengan 2,99 maka perusahaan diklasifikasikan berada pada zona rawan (grey) atau menuju kondisi terindikasi mengalami financial distress.

3. Jika nilai indeks $\mathrm{Z}$ lebih besar dari 2,99 (>2,99) maka dapat diklasifikasikan tidak terindikasi mengalami financial distress atau dalam keadaan sehat (healty)

Working Capital to Total Assets Ratio
Rasio ini memperlihatkan kemampuan perusahaan dalam menghasilkan modal kerja bersih dari seluruh total aset yang dimiliki. Rasio ini dihitung dengan cara modal kerja bersih dibagi dengan total aset. Modal kerja dihitung dengan cara aset lancar dikurangi dengan kewajiban (Sondakh, et al.2014:368).

Retained Earning to Total Assets Ratio

Rasio ini menunjukkan
kemampuan perusahaan dalam menghasilkan laba ditahan dari total aset perusahaan. Laba ditahan dapat terbentuk dikarenakan para pemegang saham biasa memberikan izin kepada perusahaan untuk menginvestasikan kembali laba dengan tujuan tertentu dan tidak dibagikan dalam bentuk dividen.

\section{Earning Before Interest and Taxes to Total Assets Ratio}

Rasio ini menggambarkan
kemampuan perusahaan dalam
menghasilkan laba dari aset
perusahaan, sebelum pembayaran
bunga dan pajak (Endri, 2009). Rasio
ini bermanfaat dalam mengukur
profitabilitas suatu usaha dengan
tidak memandang berapa besar
hutang dari perusahaan tersebut
(Sugianto, 2017:31). Semakin kecil
nilai rasio EBIT to TA ini
mencerminkan bahwa kemampuan
perusahaan untuk memperoleh laba
sebelum bunga dan pajak dari aset
yang dimiliki semakin kecil, sehingga
kemungkinan perusahaan mengalami
financial distress semakin tinggi
(Irfan. 2014 dalam Sugianto.
2017:31).

\section{Return On Assets (ROA)}

Merupakan rasio profitabilitas yang menunjukkan persentase keuntungan (laba bersih) yang 
diperoleh perusahaan sehubungan dengan keseluruhan sumber daya (Kho. 2017 : 1). Rasio ini berguna untuk mengukur seberapa efisiennya suatu perusahaan untuk mengubah uang yang digunakan untuk membeli aset menjadi laba bersih.

\section{Sales to Total Assets Ratio}

Merupakan rasio yang menujukkan apakah suatu perusahaan menghasilkan volume usaha yang mencukupi dibandingkan dengan investasi pada total asetnya (Sondakh, et al (2014:368). Tingkat efisiensi manajemen dalam mempergunakan seluruh aset perusahaan dalam menghasilkan penjualan dan laba yang didapatkan tergambar pada rasio ini.

\section{Market Value of Equity to Book Value Liabilities Ratio}

Rasio nilai pasar modal sendiri terhadap nilai buku hutang menujukkan kemampuan perusahaan dalam memenuhi beberapa kewajiban dari nilai pasar modal sendiri (saham biasa) (Sugianto. 2017:31).Nilai pasar modal sendiri diperoleh dengan mengalikan harga pasar per lembar saham biasa dengan jumlah lembar saham biasa yang beredar. Nilai buku hutang diperoleh dengan cara menjumlahkan hutang jangka pendek dengan hutang jangka panjang (Ulfa. 2009 dalam Sugianto.2017:31).

\section{Debt Ratio}

Debt ratio atau rasio hutang merupakan rasio yang dapat dipergunakan dalam menghitung besarnya jumlah porsi dana yang berasal dari hutang, baik hutang lancar maupun hutang jangka panjang (Rohman.2018:2). Rasio ini menggambarkan berapa jumlah hutang yang dapat dipenuhi oleh asetnya.Semakin kecil rasio hutang perusahaan maka semakin aman perusahaan tersebut dari kesulitan keuangan (Rohman. 2018:3).

\section{Current Ratio}

Current ratio atau rasio lancar merupakan rasio atas perbandingan antara aset lancar dengan kewajiban lancar. Likuiditas perusahaan dikatakan baik jika nilai rasionya sama dengan 2 (Sondakh, et al. 2014:369). Sehingga semakin tinggi rasio lancar suatu perusahaan, maka semakin tinggi pula kemampuan perusahaan dalam memenuhi kewajiban lancarnya (Rohman.2018:2).

\section{METODE PENELITIAN}

\section{Jenis Penelitian}

Strategi penelitian yang digunakan dalam penelitian ini adalah deskriptif dimana digunakan untuk menggambarkan kejadian atau situasi yang ada dengan tujuan memberikan gambaran yang akurat dari sebuah data menggambarkan suatu proses, mekanisme, atau hubungan antar kejadian (Hendryadi. 2018).

\section{Populasi dan Sampel Penelitian}

Jumlah populasi dalam penelitian ini adalah 140 perusahaan manufaktur yang terdaftar di Bursa Efek Indonesia (BEI) untuk periode 2015 sampai dengan 2017. Teknik pemilihan sampel menggunakan purposive sampling dimana sampel diambil dengan kriteria, maksud tujuan tertentu. Sampel yang memenuhi kriteria dalam penelitian ini berjumlah 16 perusahaan dengan tahun pengamatan selama 3 tahun. 
Diana S, Icuk RB \& Kusriyadi CA, Analisis Perbandingan Model Springate...

\section{Metoda Analisis Data}

Dalam proses analisis data dalam penelitian ini, peneliti mempergunakan model Springate, Zmijewski dan Altman. Selanjutnya menghitung jumlah hasil prediksi dari masing-masing model untuk 3 tahun pengamatan yaitu 2015, 2016, 2017.

\section{HASIL DAN PEMBAHASAN}

Dari hasil analisis prediksi financial distress dari ketiga model ini telah diklasifikasikan berdasarkan nilai indeks dari masing-masing model. Untuk model Springate terdapat dua klasifikasi yaitu terindikasi mengalami financial distress jika nilai indeks $\mathrm{S}<0,862$, dan tidak terindikasi mengalami financial distress jika nilai indeks $\mathrm{S}>$ $/=0,862$. Untuk model Zmijewski terdapat dua klasifikasi yaitu terindikasi mengalami financial distress jika nilai indeks $\mathrm{X}>/=0$, dan tidak terindikasi mengalami financial distress jika nilai indeks $\mathrm{X}<0$. Untuk model Altman terdapat tiga klasifikasi yaitu klasifikasi terindikasi mengalami financial distress jika nilai indeks $\mathrm{Z}<1,8$, klasifikasi berada pada zona rawan atau menuju kondisi terindikasi mengalami financial distress jika nilai indeks $Z>1,8$ dan < 2,99, dan klasifikasi tidak terindikasi mengalami financial distress jika nilai indeks $Z>2,99$.

\section{Gambar 1 \\ Hasil Analisis Prediksi Financial Distress}

\section{Hasil Analisis Prediksi Financial Distress}

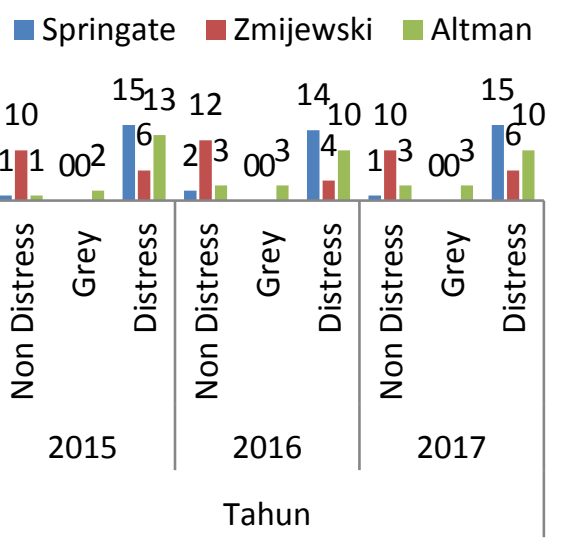

Sumber: diolah oleh penulis (2019)

Berdasarkan data hasil analisi prediksi financial distress di atas maka dapat diuraikan sebagai berikut:

Pada tahun 2015, terdapat 1 perusahaan yang diklasifikasikan tidak terindikasi mengalami financial distress untuk model Springate, terdapat 10 perusahaan yang tidak terindikasi mengalami financial distress untuk model Zmijewski dan terdapat 1 perusahaan yang tidak terindikasi mengalami financial distressuntuk model Altman. Terdapat 2 perusahaan yang diklasifikasikan berada pada zona rawan (grey) atau berada pada kondisi menuju terindikasi mengalami financial distress. Selanjutnya terdapat 15 perusahaan yang diklasifikasikan terindikasi mengalami financial ditress untuk model Springate, terdapat 6 perusahaan yang 
diklasifikasikan terindikasi mengalami financial distress untuk model Zmijewski, dan terdapat 13 perusahaan yang diklasifikasikan terindikasi mengalami financial distress untuk model Altman.

Pada tahun 2016, terdapat 2 perusahaan yang diklasifikasikan tidak terindikasi mengalami financial distress untuk model Springate, terdapat 12 perusahaan yang diklasifikasikan tidak terindikasi mengalami financial distress untuk model Zmijewski, dan terdapat 3 perusahaan yang diklasifikasikan tidak terindikasi mengalami financial distress untuk model Altman.Kemudian terdapat 3 perusahaan yang diklasifikasikan berada pada zona rawan (grey) atau menuju kondisi terindikasi mengalami financial distress untuk model Altman. Selanjutnya terdapat 14 perusahaan yang diklasifikasikan terindikasi mengalami financial distress untuk model Springate, terdapat 4 perusahaan yang diklasifikasikan terindikasi mengalami financial distress untuk model Zmijewski, dan terdapat 10 perusahaan yang diklasifikasikan terindikasi mengalami financial distress untuk model Altman.

Pada tahun 2017, terdapat 1 perusahaan yang diklasifikasikan tidak terindikasi mengalami financial distress untuk model Springate, terdapat 10 perusahaan yang diklasifikasikan tidak terindikasi mengalami financial distress untuk model Zmijewski, dan terdapat 3 perusahaan yang diklasifikasikan tidak terindikasi mengalami financial distress untuk model Altman. Kemudian terdapat 3 perusahaan yang diklasifikasikan berada pada zona rawan (grey) atau menuju kondisi terindikasi mengalami financial distress. Selanjutnya terdapat 15 perusahaan yang diklasifikasikan terindikasi mengalami financial distress untuk model Springate, terdapat 6 perusahaan yang diklasifikasikan terindikasi mengalami financial distress untuk model Zmijewski dan terdapat 10 perusahaan yang terindikasi mengalami financial distress untuk model Altman.

Total hasil analisis prediksi financial distress pada perusahaan manufaktur dengan ketiga model tersebut sebagai berikut:

a. Model Springate mengklasifikasikan $\quad 44$ perusahaan terindikasi mengalami financial distress, dan 4 perusahaan tidak terindikasi mengalami financial distress.

b. Model Zmijewski mengklasifikasikan $\quad 16$ perusahaan terindikasi mengalami financial distress, dan 32 perusahaan tidak terindikasi mengalami financial distress.

c. Model Altman mengklasifikasikan 33 perusahaan terindikasi mengalami financial distress, 8 perusahaan berada pada zona rawan (grey) atau menuju kondisi terindikasi mengalami financial distress, dan 7 perusahaan tidak terindikasi mengalami financial distress. 
Diana S, Icuk RB \& Kusriyadi CA, Analisis Perbandingan Model Springate...

\section{KESIMPULAN}

Dari hasil pembahasan pada bab-bab sebelumnya, maka dapat ditarik kesimpulan sebagai berikut:

1. Kondisi keuangan perusahaan manufaktur berdasarkan model Springate, untuk tahun 2015 terdapat 15 perusahaan diklasifikasikan terindikasi mengalami financial distress dan 1 perusahaan diklasifikasikan tidak terindikasi mengalami financial distress. Untuk tahun 2016 terdapat 14 perusahaan diklasifikasikan terindikasi mengalami financial distress dan 2 perusahaan diklasifikasikan tidak terindikasi mengalami financial distress. Untuk tahun 2017 terdapat 15 perusahaan diklasifikasikan tidak terindikasi mengalami financial distress dan 1 perusahaan diklasifikasikan tidak terindikasi mengalami financial distress.

2. Kondisi keuangan perusahaan manufaktur berdasarkan model Zmijewski, untuk tahun 2015 terdapat 6 perusahaan diklasifikasikan terindikasi mengalami financial distress dan 10 perusahaan diklasifikasikan tidak terindikasi mengalami financial distress. Untuk tahun 2016, terdapat 4 perusahaan diklasifikasikan terindikasi mengalami financial distress dan 12 perusahaan diklasifikasikan tidak terindikasi mengalami financial distress. Untuk tahun 2017 terdapat 6 perusahaan diklasifikasikan terindikasi mengalami financial distress dan 10 perusahaan diklasifikasikan tidak terindikasi mengalami financial distress.
3. Kondisi keuangan perusahaan manufaktur berdasarkan model Altman, untuk tahun 2015 terdapat 13 perusahaan diklasifikasikan terindikasi mengalami financial distress dan terdapat 2 perusahaan diklasifikasikan berada zona rawan (grey) untuk menuju kondisi terindikasi mengalami financial distress serta terdapat 1 perusahaan diklasifikasikan tidak terindikasi mengalami financial distress. Untuk tahun 2016, terdapat 10 perusahaan diklasifikasikan terindikasi mengalami financial distress dan terdapat 3 perusahaan diklasifikasikan berada pada zona rawan (grey) untuk menuju kondisi terindikasi mengalami financial distress serta terdapat 3 perusahaan diklasifikasikan tidak terindikasi mengalami financial distress. Untuk tahun 2017 terdapat 10 perusahaan diklasifikasikan terindikasi mengalami financial distress dan terdapat 3 perusahaan diklasifikasikan berada pada zona rawan (grey) untuk menuju kondisi terindikasi mengalami financial distress, serta terdapat 3 perusahaan diklasifikasikan tidak terindikasi mengalami financial distress.

4. Jumlah hasil analisis prediksi financial distress pada perusahaan manufaktur untuk model Springate mengklasifikasikan $\quad 44$ perusahaan yang terindikasi mengalami financial distress dan mengklasifikasikan 4 perusahaan tidak terindikasi mengalami financial distress. Untuk model Zmijewski mengklasifikasikan 
16 perusahaan yang terindikasi mengalami financial distress dan mengklasifikasikan 32 perusahaan tidak terindikasi mengalami financial distress. Untuk model Altman mengklasifikasikan 33 perusahaan yang terindikasi mengalami financial distress dan mengklasifikasikan 8 perusahaan berada pada zona rawan (grey) untuk menuju kondisi terindikasi mengalami financial distress serta mengklasifikasikan 7 perusahaan tidak terindikasi mengalami financial distress.Sehingga dapat ditarik kesimpulan bahwa model prediksi yang dapat mengindikasikan financial distress yang lebih baik adalah model Springate.

Saran-saran untuk penelitian selanjutnya adalah dengan mempergunakan sampel dari seluruh perusahaan manufaktur yang terdafar di Bursa Efek Indonesia (BEI) agar diperoleh hasil prediksi yang lebih baik dan lebih menyeluruh.

Keterbatasan dalam penelitian ini adalah proses input data dan perhitungan secara manual sehingga berpeluang untuk terjadi kesalahan hitung dan hanya mempergunakan tiga model prediksi financial distress.

\section{REFERENSI}

Alali, Musaed. S. 2018. Predicting Financial Distress For Mobile Telecomunication Companies Listed In Kuwait Exchange Using Altman's Model. Journal of Economics, Finance and Accounting Volume 5

Aminian, et al. 2016. Investigate the Ability of Bankruptcy Prediction Models of Altman and Springate and Zmijewski and Grover in Tehran Stock Exchange. Mediterranean Journal of Social Sciences Vol 7 No. 4

Aprilyani, Jane. 2018. Truba Alam Delisting Investor Jual Cepat Sahamnya. Kontan.co.id. Di unduh pada 9 Desember 2018

Arief, Tegar. 2018. Merger Jaya Pari Steel Akan Delisting 8 Oktober 2018. Bisnis.com. Di unduh pada 9 Desember 2018

Carolina, et al. 2017. Analisis Rasio Keuangan Untuk Memprediksi Kondisi Financial Distress. Jurnal Akuntansi Maranatha Vol. 9 No. 2

Curry dan Banjarnahor. 2018. Financial Distress Pada Perusahaan Sektor Properti Go Public di Indonesia. Seminar Nasional Pakar ke 1

Dewi, Nur. Fajrina. 2014. Model Prediksi Financial Distress Untuk Mendeteksi Potensi Kebankrutan Pada Industri Perbankan. Tugas Akhir

Dwijayanti, Febriana. Patricia. S. 2010. Penyebab, Dampak, Dan Prediksi Dari Financial Distress Serta Solusi Untuk Mengatasi Financial Distress. Jurnal Akuntansi Kontemporer. Vol. 2 No. 2

Fahreza. Dimas. 2017. Rasio KeuanganArti Jenis dan Rumusnya. https://zahiraccounting.com. Di unduh pada 31 Desember 2018

Hapsari, Indri. Evanny. 2012. Kekuatan Rasio Keuangan Dalam Memprediksi Kondisi Financial Distress Perusahaan Manufaktur di BEI. Jurnal Dinamika Manajemen. JDM Vol 3. No.2

Hendryadi.2018.Metode Riset Untuk Mahasiswa Bisnis dan Manajemen. Jakarta.

Hidayat dan Meiranto. 2014. PrediksiFinancial Distress Perusahaan Manufaktur di Indonesia. Diponegoro Journal of Accounting. Vol 3 Nomor 3

https://www.sahamok.com/perusahaanmanufaktur-di-bei. Di unduh pada 10 Desember 2018 
Diana S, Icuk RB \& Kusriyadi CA, Analisis Perbandingan Model Springate...

Ikatan Akuntan Indonesia. 2017. Standar Akuntansi Keuangan Efektif Per 1 Januari 2017. Di unduh tanggal 24 November 2018. http://iaiglobal.or.id.

Julius, Frans. P. S. 2017. Pengaruh Financial Leverage, Firm Growth, Laba dan Arus Kas Terhadap Financial Distress. JOM Fekon Vol.4 No. 1

Kho. Budi. 2017. Pengertian ROA (Return On Assets). https://ilmumanajemenindutri.com. Di unduh pada 23 Desember 2018

Kho. Budi. 2017. Pengertian Rasio Lancar (Current Ratio) dan Rumus Rasio Lancar.

https://ilmumanajemenindutri.com. Di unduh pada 23 Desember 2018

Kho. Budi. 2017. Pengertian Rasio Hutang (Debt Ratio) dan Rumus Rasio Hutang. https://ilmumanajemenindutri.com. Di unduh pada 23 Desember 2018

Kieso, Donald. E, et al. 2007.Akuntansi Intermediate EdisiKeduaBelas.Jakarta. Erlangga

Kieso, E. Donald., Weygandt, J. Jerry dan Warfield, D.Terry. 2008. Akuntansi Intermediate. Edisi 12. Jilid 1. Jakarta. Erlangga

Kokyung dan Khairani. 2014. Analisis Penggunaan Altman Z-score dan Springate Untuk Mengetahui Potensi Kebangkrutan pada PT Bakrie Telecom Tbk.

Kordestani, et al. 2011. Ability Of Combinations Of Cash Flow Components To Predict Financial Distress. Verslas : Teorijair Praktika Business: Theory and Practice. 277-285

Mas'ud dan Srengga. 2015. Analisis Rasio Keuangan Untuk Memprediksi Kondisi Financial Distress Perusahaan Manufaktur Yang Terdaftar Di Bursa Efek Indonesia. Jurnal Akuntansi Universitas Jember, (S.1), V.10, No 2, P 139-154
Meiliawati, Anggi. 2016. Analisis Perbandingan Model Springate Dan Altman Z-score Terhadap Potensi Financial Distress (Studi Kasus Pada Perusahaan Sektor Kosmetik Yang Terdaftar di BEI). Jurnal Akuntansi dan Pendidikan. Volume 5 Nomor 1

Muflihah, Zakiyatul. Intan. 2017. Analisis Financial Distress Perusahaan Manufaktur di Indonesia dengan Regresi Logistik. Majalah Ekonomi_ISSN No.1411-9501_Vol XXII. No.2

Mujilan. 2012. Analisis Laporan Keuangan dan Rasio Keuangan Edisi 1. Madiun. Universitas Widya Mandala

Munawir. S. 2014. Analisa Laporan Keuangan. Cetakan. 17. Jakarta. Liberty

Nukmaningtyas dan Worokinasih. 2018. Penggunaan Rasio Profitabilitas, Likuiditas, Leverage dan Arus Kas Untuk Memprediksi Financial Distress. Jurnal Administrasi Bisnis (JAB) Vol. 61 No. 2

Nurhidayah dan Rizqiyah. 2017. Kinerja Keuangan Dalam Memprediksi Financial Distress. Jurnal JIBEKA Volume 11 No. 1

Permana, et al. 2017. Prediksi Financial Distress Pada Perusahaan Manufaktur di Bursa Efek Indonesia. Jurnal Bisnis dan Manajemen. Vol 7 (2)

Prihanthini dan Sari. 2013. Prediksi Kebangkrutan Dengan Model Grover, Altman Z-score, Springate Dan Zmijewski Pada Perusahaan Food And Beverage di Bursa Efek Indonesia. EJurnal Akuntansi Universitas Udayana $5.2: 417-435$

Primasari, Savitri. Niken. 2017. Analisis Altman Z-score, Grover Score, Springate, dan Zmijewski Sebagai Signaling Financial Distress (Studi Empiris Industri Barang-Barang Konsumsi di Indonesia). Accounting and Management Journal, Vol. 1, No. 1

Purnajaya dan Merkusiwati. 2014. Analisis Komparasi Potensi Kebangkrutan Dengan Metode Z-score 
Altman, Springate, Dan Zmijewski Pada Industri Kosmetik Yang Terdaftar di Bursa Efek Indonesia. E-Jurnal Akuntansi Universitas Udayana $7.1: 48$ 63

Putera, et al. 2016. Perbandingan Prediksi Financial Distress Dengan Menggunakan Model Altman, Springate, dan Ohlson. Jurnal Wawasan Manajemen, Vol 4, Nomor 3

Rahayu, et al. 2016. Analisis Financial Distress Dengan Menggunakan Metode Altman Z-score, Springate, Dan Zmijewski Pada Perusahaan Telekomunikasi. E-Journal Bisma Universitas Pendidikan Ganesa Jurusan Manajemen Volume 4

Ratna dan Marwati. 2018. Analisis Faktor-Faktor Yang Mempengaruhi Kondisi Financial Distress Pada Perusahaan Yang Delisting Dari Jakarta Islamic Index Tahun 2012-2016. Jurnal Tabarru, Islamic Banking and Finance. V.1

Rohman, Nur. 2018. Pengertian Analisis Rasio Keuangan, Macam-Macam Rasio dan Rumusnya. Akuntanonline.com. Di unduh 9 Desember 2018

Saham Delisting 2017 di BEI. Sahamok.com. Di unduh pada 9 Desember 2018

Sari, Pradhita. Sari. 2017. Daftar Perusahaan Yang Pailit Sepanjang 2017. Bisnis.com. Di unduh pada 9 Desember 2018

Septiadi, Anggar. 2018. PT Kertas Leces Pailit Kurator Bereskan Aset. Kompas.com. Di unduh pada 9 Desember 2018

Septiadi, Anggar. 2018. Tiga Pilar Sejahtera Terancam Pailit. Kompas.com. Di unduh pada 9 Desember 2018

Sondakh, et al. 2014. Analisis Potensi Kebangkrutan Dengan Menggunakan Metode Altman Z-score, Springate dan Zmijewski Pada Industri Perdagangan Ritel Yang Terdaftar di BEI Periode
2009-2013. Jurnal EMBA, Vol. 2 No. 4 : 364-373.

Subramanyam, K.Rdan Wild, John.J. 2014. AnalisisLaporanKeuangan. Edisi 10.Jakarta.SalembaEmpat

Sugianto, Dewi. Wulansari. 2017. Analisis Financial Distress Pada Perusahaan Manufaktur Yang Terdaftar di Bursa Efek Indonesia Tahun 20132015. Skripsi

Suprihatin dan Mansur. 2016. Pengaruh Rasio Keuangan dan Reputasi Underwriter Terhadap Financial Distress Pada Perusahaan Manufaktur Yang Terdaftar di Bursa Efek Indonesia (BEI) Periode 2005-2008. Jurnal Akuntansi Vol 3 No. 1

Tjahjono dan Novitasari. 2016. Analisis Rasio Keuangan Untuk Memprediksi Kondisi Financial Distress Perusahaan Manufaktur. Jurnal Kajian Bisnis Vol.24 No. 2

Utami, Widya. Novia. 2018. Mengenal dan Mencegah Terjadinya Financial Distress Dalam Perusahaan. www.jurnal.id. Di unduh tanggal 31 Desember 2018

Yollawan. H. 2018. BEI Delisting Sudah Ada Mekanisme Dan Aturan Yang Berlaku. Kontan.co.id. Di unduh pada 9 Desember 2018

Yuliastary dan Wirakusuma. 2014. Analisis Financial Distress Dengan Metode Z-score Altman, Springate, Zmijewski.E-Jurnal Akuntansi Universitas Udayana 6.3 : 379-389

www.okezone.com 